\title{
膀胼癌に対する高線量率腔内放射線療法に関する基礎的，臨床的研究
}

\author{
関西労災病院泌尿器科 (部長 : 広岡九兵衛) \\ 井上 隆朗* 島谷昇広岡九兵衛 \\ 神戸大学医学部泌尿器科学教室 (主任 : 守殿貞夫教授) \\ 守 殿 貞 夫
}

\section{BASIC AND CLINICAL STUDY OF HIGH DOSE RATE INTRACAVITARY RADIOTHERAPY OF BLADDER TUMOR}

\author{
Takaaki Inoue, Nobori Shimatani and Kuhei Hirooka \\ Department of Urology, Kansai Rosai Hospital \\ (Director: K. Hirooka) \\ Sadao Kamidono \\ Department of Urology, School of Medicine, Kobe University
}

(Director: Prof. S. Kamidono)

Since 1984, through 8 years, 29 cases of bladder tumor were treated with high dose rate intracavitary radiotherapy. All cases were transitional cell carcinoma in histology and consisted of 12 cases of CIS, 7 of Ta, 3 of T1, 1 of T2 and 6 of T3. At the intracavitary therapy, 3-way catheter made specially for high dose rate intracavitary radiotherapy was inserted into the bladder and the balloon of the catheter was inflated with air of 80 to $100 \mathrm{ml}$. A radioactive source of ${ }^{60} \mathrm{Co}$ was remotely controlled and drove through the catheter into the bladder. The delivered dose was $5 \mathrm{~Gy}$ per fraction and total dose was 40 to $50 \mathrm{~Gy}$ in 8 to 10 fractions. Complete response (CR) rate was 7/12 (58.3\%) in CIS, 4/6 in $\mathrm{Ta}, 1 / 3$ in $\mathrm{T} 1,1 / 1$ in T2 and $1 / 6$ in T3. CR rate of CIS and superficial tumor (Ta, Tl) was $57.1 \%(12 / 21)$, whereas that of invasive cancer was $2 / 7$. Regarding complications, one case suffered severe cystitis as an acute reaction, however, the remaining cases only noted a mild or moderate acute reaction. It was concluded that high dose rate intracavitary radiotherapy was a useful treatment for CIS of the bladder and superficial bladder cancer.

Key words: bladder tumor, remote afterloading, intracavitary radiotherapy

\footnotetext{
要旨：1984年より1991年までの 8 年間に当科で加療した膀胱癌のうち29例に対し, 高線量率腔内放射線 療法を施行した。全例，移行上皮癌であり，その浸潤度は，CIS 12例，Ta 7 例，T1 3 例，T2 1 例，T3 6 例であった. 照射には, 3-way カテーテルを特別に作成し, 80 100 $\mathrm{ml}$ の空気で膀胱を拡張させ, リモー トコントロールにて ${ }^{60} \mathrm{Co}$ の線源を膀胱の中央に留置し照射を行った。投与線量は，一回 $5 \mathrm{~Gy}$ ，計 $8 \sim 10$ 回, 総線量として40５0Gy を標準した. CR 率は, CIS 7/12 (58.3\%), Ta 4/6, T1 1/3，T2 1/1，T3 1/6で，CIS および Ta，T1の表在性腫瘍では $12 / 21(57.1 \%)$ と高率であったのに対し，浸潤性腫瘍では 2/7 と低率であった。副反応は，1例で強い膀胱炎症状がみられた以外，重篤なものはみられなかった。 本療法は, 膀胱上皮内癌および表在性膀胖癌に有効な治療法と考兄られた。 キーワード：膀胱癌, 遠隔操作, 腔内照射法
}

緒言

膀胱癌は, 尿路性器癌のうち最も高頻度にみられる

* 現 神戸大学医学部泌尿器科学教室
腫瘍であり，近年さらに増加しつつあることから，泌 尿器科医にとり極めて重要な疾患である。その治療は, 腫瘍の浸潤度と細胞異型度を指標として, 手術療法を 中心に種々の方法が用いられている11. 
一般に, 表在性腫湯に対しては経尿道的手術(TUR) が行われ，比較的良好な結果がえられている。しかし， 表在性腫瘍でありながら浸潤傾向の強い carcinoma in situ (CIS) に対する治療法選択ならびに術後の高頻 度にみられる再発に関する問題などがある。

一方, 浸潤性腫瘍においては手術療法のみでは予後 良好とはい方ず2)，化学療法や放射線療法との併用に よる集学的治療が行われているが，いまだ標準的な治 療法は確立されていない。

膀胖腫瘍に対する治療法のなかで, 放射線療法は, 膀胱機能の温存や侵襲の少なさ等の多くの利点をもつ が，単独での治療効果は満足すべきものではない。李 た, 照射による膀胱及び周囲葴器への副反応の問題等 もあり，わが国では根治的療法としてはあまり積極的 には行われず, 術前, 術後の補助療法として, または, 手術不能例に対する姑息的な外照射が行われてき た ${ }^{3)}$.これに対し，欧米では外照射のみばかりでなく， 副反応が少なく，かつ有効な照射法として，小線源を 用いた組織内照射や腔内照射等が試みられている。そ こで, 我々もこの観点より, 子宮頸癌の標準治療とし て定着している高線量率腔内照射療法 (High dose rate remote afterloading system, RALS）を膀胱腫 瘍に初めて応用し若干の知見をえたので報告する。

\section{基礎的検討}

\section{1. 装置}

照射装置は，アフターローディング式体腔治療装置 RAL303型（Toshiba Medical Co., Ltd, Tokyo）で ある。この装置は, あらかじめ照射目的部位にアプリ ケーターを挿入して遠隔操作により線源を送り込むも ので，アプリケーター内の任意の位置に任意の時間, 線源を留置することが可能である。線源収納容器, 線 源を移送するための駆動器, および収納容器とアプリ ケーターを接続する案内管より構成される。線源は60 Co を用い, アプリケーターとして, 子宮頸癌の腔内照 射用タンデム型ポリエチレン製チューブを使用した。 またこのチューブを膀脱内に挿入するために，照射 用尿道カテーテルとして，24Fr，3-Wayカテーテル （Create Medic Co., Ltd）を特別に作成した。このカ テーテルは，中心に線源挿入用ルート，外側にバルー ン拡張用，および膀胱内注入用ルートをもち，膀胱壁 全面に均一な線量が照射されるように，できるだけバ ルーンが均等に拡張し，またカテーテル先端による膀 脱の変形を防ぐために，バルーン先端の突出を可能な 限り短くしたものである。この照射用カテーテル内に
ポリエチレンチューブる挿入し，ポリエチレンチュー ブとRALSを接続することにより線源が膀胱内に留 置されることになる。このほかに，線源位置を決定す るための模擬線源も使用した。これは，実際の照射前 にポリエチレンチューブ内に挿入し，膀胼像を撮影す ることにより線源位置決定の指標とする（Fig. 1).

\section{2. 照射手技}

患者に砕石位をとらせ，キシロカインゼリーによる 尿道粘膜麻酔を行い, 導尿後, 前述の照射用カテーテ ルを尿道より膀胱内に挿入乙，バルーン内に $80 \sim 100$ $\mathrm{ml}$ の空気を注入する。 その後, 膀脱形状をみるためイ リゲーションルートより小量の造影剂を膀胱内に注入 した後，模擬線源を入れたポリェチレンチューブを線 源挿入ルートより入れる。膀胱正面および側面像の撮 影にて, バルーンにより膀胼が均等に拡張しているか, 残尿による膀胱の変形はないか等を確認し，線源を留 置する位置を決定寸る (Fig. 2)，我々は，膀脱壁全体 への均等照射を目的とするには，線源の位置は可及的 膀脱中央が適切と考㝋られることから，膀胱の中央に 最も近い点として膀胱正面像における頂部，頸部間の 中央を選択した。本照射法の特長は, 線量分布 (Fig. 3) からわかるように，線源からの距離が離れるにしたが い, 吸収線量が著明に減少する点で, 周囲臓器への影 響は少ない。しかし，実際には放射線感受性の最も高 い直腸の被爆線量を測定する目的で，直腸内に線量計 を挿入しておく. 以上の操作終了後，ポリエチレン チューブと線源移送用案内管を連結し，操作室よりの リモートコントロールにより膀脱内に線源を留置し, 計画した線量を照射する，照射終了後，線源を同様に リモートコントロールにより収納庫に格納し，尿道カ テーテルを技去して治療を終える，患者の麻䣲開始か ら照射終了までの時間は約30分，実際の照射時間は約

Fig. 1 Devices for high dose rate intracavitary therapy of bladder tumor. Intracavitary catheter (A), source tube (B) and dammy source (C).

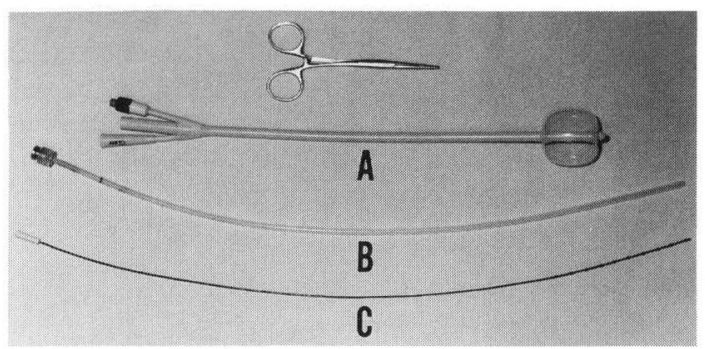


Fig. 2 Roentgen photograms of Intracavitary Radiotherapy. anteroposterior (A), lateral (B).
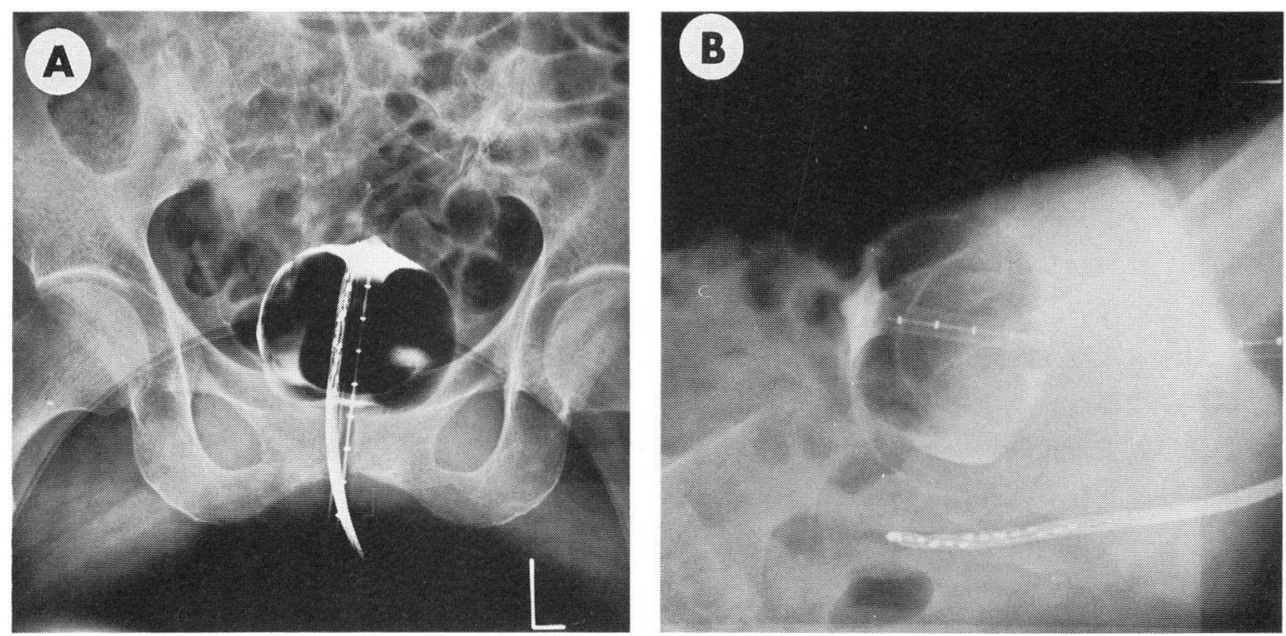

Fig. 3 Dose distribution of Intracavitary Radiotherapy of bladder tumor. The dose dropped rapidly at a small distance from the source.

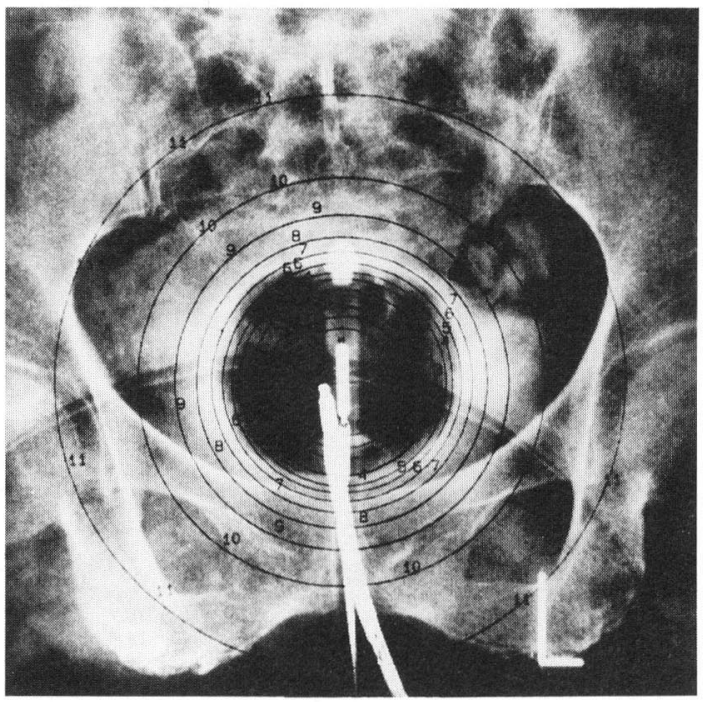

Application time : $5.75 \mathrm{~min}$

Dose at mucosa of Bladder : $5 \mathrm{~Gy}$

(Distance between source and mucosa

(Distance
$30 \mathrm{~mm}$ )

Isodose (rad)

03,000

12,000

21,500

31,000

4800

5700

6600

7500

8400

9300

$10 \quad 200$

$11 \quad 100$

5 分前後である. 線源挿入, 抜去は, すべて遠隔操作 室からのリモートコントロールにて行われるため，医 療従事者の被曝は全くない。

\section{臨床的検討}

\section{1. 症例}

1984年10月より1991年 3 月までに当科に入院した膀 胱癌患者29例を対象とした（Table 1，2，3）。

性別は, 男性 20 例, 女性 9 例, 年齡は, 55 歳上り93
歳, 平均75歳, 初発腫瘍15例, 再発腫痬14例であった。 再発例14例では, 前治療として TUR もしくは膀脱部 分切除，またはその両者が併用されており，このらち 4 例で Adriamycin (ADM), 2 例で Mitomycin C (MMC) の膀注の治療歴があった。

組織型は全例移行上皮癌で, 異型度は, Grade 14 例, Grade 2 16例, Grade 39 例であった。浸潤度は, CIS 12例, Ta 7 例, T1 3 例, T2 1 例, T3 6 例で, 
Table 1 Patients characteristics (1)

\begin{tabular}{|c|c|c|c|c|}
\hline No-Age-Sex & Stage & Grade & $\begin{array}{l}\text { Previous } \\
\text { treatment }\end{array}$ & Cytology \\
\hline $1-71-M$ & $\mathrm{CIS}$ & 3 & $(-)$ & 4 \\
\hline $2-75-M$ & CIS & 2 & TUR $\times 1$ & 5 \\
\hline $3-70-M$ & CIS & 3 & TUR $\times 2$ & 4 \\
\hline $4-69-M$ & CIS & 3 & $(-)$ & 5 \\
\hline $5-58-M$ & CIS & 2 & $(-)$ & 5 \\
\hline $6-73-M$ & CIS & 2 & $\begin{array}{l}\text { Partial cystectomy } \\
\text { ADM instillation }\end{array}$ & 3 \\
\hline $7-67-F$ & CIS & 2 & $(-)$ & 2 \\
\hline $8-79-F$ & CIS & 3 & $(-)$ & 5 \\
\hline $9-79-F$ & CIS & 2 & $\begin{array}{c}\text { TUR } \times 10 \\
\text { MMC instillation }\end{array}$ & 2 \\
\hline $10-82-F$ & CIS & 1 & Nephroureterectomy & 5 \\
\hline $11-93-M$ & CIS & 3 & $\begin{array}{c}\text { TUR } \times 1 \\
\text { ADM instillation }\end{array}$ & 5 \\
\hline $12-88-M$ & CIS & 2 & Nephroureterectomy & 4 \\
\hline
\end{tabular}

Table 2 Patients characteristics (2)

\begin{tabular}{|c|c|c|c|c|c|}
\hline No-Age-Sex & Stage & Grade & $\begin{array}{l}\text { Previous } \\
\text { treatment }\end{array}$ & Cytology & $\begin{array}{r}\text { Cystoscopical } \\
\text { findings } \\
\end{array}$ \\
\hline $13-79-M$ & $\mathrm{Ta}$ & 2 & TUR $\times 5$ & 2 & papillary,multiple \\
\hline $14-77-F$ & $\mathrm{Ta} / \mathrm{CIS}$ & 2 & $\begin{array}{l}\text { Partial cystectomy } \\
\text { TUR } \times 2\end{array}$ & 5 & $\begin{array}{l}\text { papillary,solitary } \\
\text { redness }\end{array}$ \\
\hline $15 \cdot 71-M$ & $\mathrm{Ta} / \mathrm{CIS}$ & 1 & $\begin{array}{c}\text { Nephroureterectomy } \\
\text { TUR } \times 2 \\
\text { MMC instillation }\end{array}$ & 5 & $\begin{array}{l}\text { papillary,solitary } \\
\text { redness }\end{array}$ \\
\hline $16-74-M$ & $\mathrm{Ta} / \mathrm{CIS}$ & 2 & $(-)$ & 2 & $\begin{array}{l}\text { papillary,solitary } \\
\text { erosion }\end{array}$ \\
\hline $17-80-F$ & $\mathrm{Ta}$ & 3 & $\begin{array}{c}\text { Nephroureterectomy } \\
\text { TUR } \times 2\end{array}$ & 4 & papillary,solitary \\
\hline $18 \cdot 59 \cdot M$ & $\mathrm{Ta}$ & 1 & TUR $\times 1$ & 3 & papillary,multiple \\
\hline $19-77-M$ & $\mathrm{Ta} / \mathrm{CIS}$ & 1 & $\begin{array}{c}\text { TUR } \times 4 \\
\text { ADM instillation }\end{array}$ & 2 & papillary,solitary \\
\hline $20-74-M$ & T1 & 2 & $(-)$ & 5 & papillary,multiple \\
\hline $21-68-M$ & $\mathrm{~T} 1$ & 2 & $(-)$ & NE & papillary,multiple \\
\hline $22-80-M$ & $T_{1}$ & 2 & TUR $\times 4$ & 5 & papillary,multiple \\
\hline
\end{tabular}

Table 3 Patients characteristics (3)

\begin{tabular}{lccccl}
\hline No-Age-Sex & Stage & Grade & $\begin{array}{c}\text { Previous } \\
\text { treatment }\end{array}$ & Cytology & $\begin{array}{c}\text { Cystoscopical } \\
\text { findings }\end{array}$ \\
\hline $23-55-\mathrm{F}$ & T2/CIS & 3 & TURX3 & 5 & $\begin{array}{l}\text { non-papillary } \\
\text { erosion } \\
\text { non-papillary }\end{array}$ \\
$24-75-\mathrm{M}$ & T3 & 3 & $\begin{array}{c}\text { Partial cystectomy } \\
\text { TURX1 }\end{array}$ & 5 & \\
ADM instillation & & \\
$25-71-\mathrm{F}$ & T3 & 3 & $(-)$ & 5 & non-papillary \\
$26-74-\mathrm{M}$ & T3 & 2 & $(-)$ & 4 & non-papillary \\
$27-87-\mathrm{F}$ & T3 & 2 & $(-)$ & 2 & papillary \\
$28-84-\mathrm{M}$ & T3 & 2 & $(-)$ & 5 & non-papillary \\
$29-85-\mathrm{M}$ & T3 & 2 & $(-)$ & 5 & non-papillary \\
\hline & & & & &
\end{tabular}

全例遠隔転移を認めなかった。 Ta，T1，T2の11例に おいては，5例が腫瘍周囲に広範な随伴性 CIS， 1 例が 広範な dysplasia，5例が多発性腫瘍を有し，経尿道的 手術のみでは根治的治療が不十分と考えられたため, 腔内照射を適応とした。また，T3のらち 1 例は術前照 射として，他の 5 例は全身状態または患者の膀胱全摘 拒否のため膀脱全摘除術を施行できなかったため本療
Fig. 4 Total bladder dose. Total delivered dose to the bladder was more than $40 \mathrm{~Gy}$ in 19 cases.

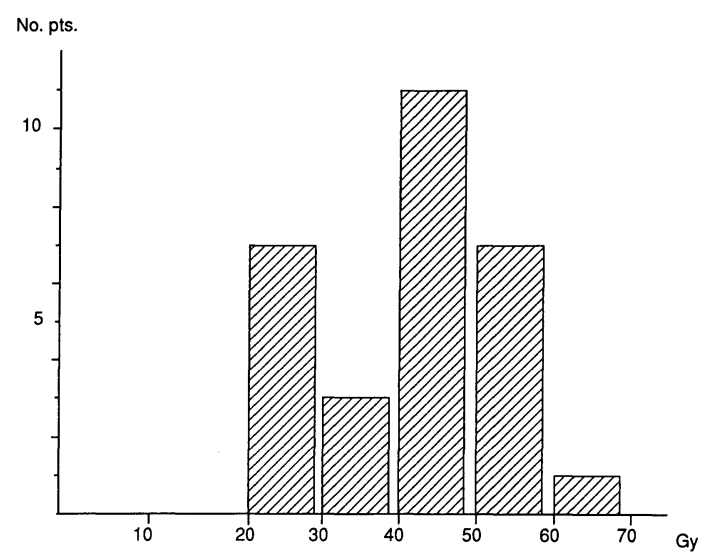

法を行った。なお，本治療法を行うにあたり，患者に は他の治療法を説明した上で承諾を得た。

2. 治療法

照射線量としては，頸部，頂部，左右側壁の 4 点の らち最も線源より遠い点に一回，5Gy が照射されるよ 5に投与し，これを週 2 回，計 $8 \sim 10$ 回，総線量とし て40～50Gy を標準とした。 しかし，治療開始当初は副 反応等を考慮し, 計画線量より少ない投与線量より開 始した。結果的に，一回線量は $4 \sim 8 \mathrm{~Gy}$ ，週 $1 \sim 2$ 回， 照射回数は 4 〜 12回であり，総線量は, 20〜30Gy 未満 7 例, $30 \sim 40 \mathrm{~Gy}$ 未満 3 例, $40 \sim 50 \mathrm{~Gy}$ 未満11例, $50 \mathrm{~Gy}$ 7 例，60Gy 1 例であった (Fig. 4). 併用療法として, Ta の 2 例で照射前に乳頭状腫瘍の TUR を施行, CIS の 5 例, T3の 1 例で照射後に根治を目的として膀胼全 摘術，Ta，T1の 3 例で照射後の残存腫瘍に対し TUR (TUEC), T3の 1 例で外照射をそれぞれ行い，他の 17 例は無治療にて経過観察した。

\section{3. 臨床成績}

(1) 効果判定法

尿細胞診についてはCISにおいて評価し，照射前 Class 4以上であったものが照射後 Class 3 以下となっ たものを有効, 照射後もClass 4 以上であったものを無 効とした。膀胱鏡所見は CIS を除く Ta〜T3の症例に おいて評価し，腫瘍所見が消失したものを有効，残存 のみられたものを無効とした。組織学的効果は，照射 後の全摘標本または生検標本で，大星，下里の分類を 用い，全 Stage において評価し，Grade 3 以上を有効， Grade 2以下を無効とした. Dysplasia の 1 例を除く28 例において，これらの方法で腫瘍に対する効果を検討 
した。しかし，症例により施行されなかった項目もあ り, 結果として CIS では10例で尿細胞診および組織学 的所見, 2 例で組織学的所見, 1 例で尿細胞診, Ta 〜 T1では 3 例で膀胼鏡所見および組織学的所見， 5 例 で膀胱鏡所見， 1 例で組織学的所見，T3では全例で膀 胼鏡所見および組織学的所見により評価がなされた。 総合効果判定として，評価可能であった項目が有効で あった症例を CR (Complete response), 一つでも無 効であった症例を NC（No change）とした。また， 局所制御率および生存率を Kaplan-Meier 法を用いて 検討した。

(2) 結果

Table 4 Result (1)

\begin{tabular}{|c|c|c|c|c|c|c|c|}
\hline No. & $\begin{array}{c}\text { Total } \\
\text { dose(Gy) }\end{array}$ & $\begin{array}{c}\text { Combined } \\
\text { treatment }\end{array}$ & Cytology & $\begin{array}{l}\text { Histological } \\
\text { effect* }\end{array}$ & $\begin{array}{l}\text { Recurrer } \\
\text { Local }\end{array}$ & $\begin{array}{l}\text { co(mos.) } \\
\text { Distant }\end{array}$ & $\begin{array}{c}\text { Survival } \\
\text { (mos.) }\end{array}$ \\
\hline 1 & 24 & $\begin{array}{l}\text { Total } \\
\text { cystectomy }\end{array}$ & NE & 2 & $(-)$ & $(-)$ & $\begin{array}{c}75 \\
\text { alive }\end{array}$ \\
\hline 2 & 28 & $(-)$ & 2 & NE & $(-)$ & $(-)$ & $\begin{array}{c}15 \\
\text { dead }\end{array}$ \\
\hline 3 & 20 & $\begin{array}{l}\text { Total } \\
\text { cystectomy }\end{array}$ & 5 & 3 & $(-)$ & $(-)$ & $\begin{array}{l}67 \\
\text { alive }\end{array}$ \\
\hline 4 & 25 & $\begin{array}{l}\text { Total } \\
\text { cystectomy }\end{array}$ & 3 & 2 & $(-)$ & $(-)$ & $\begin{array}{l}67 \\
\text { alive }\end{array}$ \\
\hline 5 & 40 & $\begin{array}{l}\text { Total } \\
\text { cystectomy }\end{array}$ & 3 & 4 & $(-)$ & $(-)$ & $\begin{array}{c}10 \\
\text { dead }\end{array}$ \\
\hline 6 & 20 & $\begin{array}{l}\text { Total } \\
\text { cystectomy }\end{array}$ & NE & 3 & $(-)$ & $(-)$ & $\begin{array}{l}65 \\
\text { alive }\end{array}$ \\
\hline 7 & 40 & $(-)$ & 2 & 4 & $(-)$ & $(-)$ & $\begin{array}{c}48 \\
\text { alive }\end{array}$ \\
\hline 8 & 40 & $(-)$ & 2 & 3 & 19 & $(-)$ & $\begin{array}{l}37 \\
\text { alive }\end{array}$ \\
\hline 9 & 50 & (-) & 2 & 4 & 20 & $(-)$ & $\begin{array}{c}28 \\
\text { alive }\end{array}$ \\
\hline 10 & 50 & $(-)$ & 3 & 4 & (-) & (-) & $\begin{array}{c}22 \\
\text { alive }\end{array}$ \\
\hline 11 & 50 & $(-)$ & 5 & 2 & ' & $(-)$ & $\begin{array}{l}17 \\
\text { alive }\end{array}$ \\
\hline 12 & 50 & $(-)$ & 5 & 2 & I & $(\cdot)$ & $\begin{array}{c}19 \\
\text { alive }\end{array}$ \\
\hline
\end{tabular}

NE : Not evaluated

Table 5 Result (2)

\begin{tabular}{|c|c|c|c|c|c|c|c|c|}
\hline No. & $\begin{array}{c}\text { Total } \\
\text { dose(Gy) }\end{array}$ & $\begin{array}{l}\text { Combined } \\
\text { treatment }\end{array}$ & Cystoscopy & Cytology & $\begin{array}{l}\text { Histological } \\
\text { effect }^{*}\end{array}$ & $\begin{array}{l}\text { Recurr } \\
\text { Local }\end{array}$ & $\begin{array}{l}\text { ence(mos.) } \\
\text { Distant }\end{array}$ & $\begin{array}{l}\text { Survival } \\
\text { (mos.) }\end{array}$ \\
\hline 13 & 32 & $(-)$ & NED & NE & 4 & $(-)$ & $(-)$ & $\begin{array}{c}8 \\
\text { dead }\end{array}$ \\
\hline 14 & 42 & $(-)$ & NED & 2 & NE & $(-)$ & $(-)$ & $\begin{array}{c}58 \\
\text { alive }\end{array}$ \\
\hline 15 & 36 & $(-)$ & NED & 2 & $\mathrm{NE}$ & $(-)$ & $(-)$ & $\begin{array}{l}28 \\
\text { dead }\end{array}$ \\
\hline 16 & 35 & TUEC & residual & 2 & $\mathrm{NE}$ & 12 & $(-)$ & $\begin{array}{c}35 \\
\text { alive }\end{array}$ \\
\hline 17 & 40 & TUR** & NE & 2 & NE & 27 & $(-)$ & $\begin{array}{c}31 \\
\text { alive }\end{array}$ \\
\hline 18 & 50 & TUR & residual & 2 & 2 & $(-)$ & $(-)$ & $\begin{array}{c}22 \\
\text { alive }\end{array}$ \\
\hline 19 & 40 & TUR** & $\mathrm{NE}$ & 1 & 4 & $(-)$ & $(-)$ & $\begin{array}{c}9 \\
\text { alive }\end{array}$ \\
\hline 20 & 60 & $(-)$ & NED & 2 & $N E$ & 38 & $(-)$ & $\begin{array}{c}61 \\
\text { alive }\end{array}$ \\
\hline 21 & 42 & TUR & residual & 2 & 4 & $(-)$ & $(-)$ & $\begin{array}{c}6 \\
\text { lost }\end{array}$ \\
\hline 22 & 50 & $(-)$ & residual & 4 & $\mathrm{NE}$ & ノ & $(-)$ & $\begin{array}{c}23 \\
\text { alive }\end{array}$ \\
\hline
\end{tabular}

各症例の臨床成績を Table 4，5，6 に示した。

\section{(a) 初期効果}

尿細胞診は CIS のらち10例で評価された。この10例 中, 照射前 Class 4 以上であったものは 8 例で，このう ち 5 例が照射後 Class 3 以下となり, 有効率は $5 / 8 て ゙$ あった。

膀胼鏡所見は $\mathrm{Ta}, \mathrm{T} 1$ の表在性腫瘍のうち照射前に 乳頭状腫瘍の TUR が行われた 2 例を除く 8 例, T2, T3の浸潤性腫瘍 7 例において評価された。 Ta，T1の

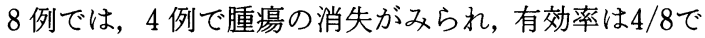
あった。一方，T2，T3の 7 例では腹瘍の消失がみられ

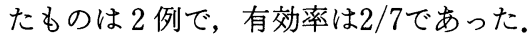

組織学的効果は, CIS のうち11例, Ta, T1の表在性 腫瘍の うち 4 例, T2, T3の浸潤性腫瘍 7 例で評価され た. CIS では照射後 Grade 3以上の効果のみられたも のは 7 例で，有効率は7/11 (63.6\%)，Ta，T1では $3 /$ 4，T2，T3では $2 / 7$ の有効率であった.

各症例の総合的効果判定では, CIS の 12 例中 CR は 7 例で, CR 率は $58.3 \%$, Ta, T1の表在性腫瘍では 9 例中 5 例で，CR 率は $55.6 \%$, T2, T3の浸潤性腫瘍で は 7 例中 2 例で $\mathrm{CR}$ 率は $28.6 \%$ であった（Table 7 ).

（b）遠隔成績

CIS 抢よび表在性腫瘍（Ta，T1）のうち，腔内照射 により CR を示し膀胱を保存した10例と，照射後の残 存腫瘍に対し TUR を施行し腫瘍を除去した 3 例，お よびdysplasia の 1 例の計14例に関する局所非再発率

Table 6 Result (3)

\begin{tabular}{|c|c|c|c|c|c|c|c|c|}
\hline No. & $\begin{array}{c}\text { Total } \\
\operatorname{dos} \theta(G y)\end{array}$ & $\begin{array}{l}\text { Combined } \\
\text { treatment }\end{array}$ & Cystoscopy & Cytology & $\begin{array}{l}\text { Histological } \\
\text { effect* }\end{array}$ & $\begin{array}{r}\text { Recurre } \\
\text { Local }\end{array}$ & $\begin{array}{l}\text { nos(mos.) } \\
\text { Distant }\end{array}$ & $\begin{array}{l}\text { Survival } \\
\text { (mos.) }\end{array}$ \\
\hline 23 & 40 & $(-)$ & NED & 2 & 4 & $(-)$ & $(\cdot)$ & $\begin{array}{c}31 \\
\text { alive }\end{array}$ \\
\hline 24 & 20 & $\begin{array}{l}\text { External } \\
\text { radiation }\end{array}$ & residual & 2 & 1 & 1 & $(-)$ & $\stackrel{8}{8}$ \\
\hline 25 & 24 & $\begin{array}{l}\text { Total } \\
\text { cystectomy }\end{array}$ & residual & 4 & 1 & (-) & 29 & $\begin{array}{c}45 \\
\text { dead }\end{array}$ \\
\hline 26 & 40 & $(-)$ & residual & 4 & 1 & I & $(-)$ & $\begin{array}{c}16 \\
\text { dead }\end{array}$ \\
\hline 27 & 45 & $(-)$ & residual & 1 & 1 & I & (-) & $\begin{array}{c}7 \\
\text { dead }\end{array}$ \\
\hline 28 & 50 & $(-)$ & residual & 3 & 2 & I & $(-)$ & $\begin{array}{c}19 \\
\text { alive }\end{array}$ \\
\hline 29 & 40 & $(-)$ & NED & 2 & 3 & $(-)$ & $(-)$ & $\begin{array}{c}16 \\
\text { alive }\end{array}$ \\
\hline
\end{tabular}

Table 7 Integrated evaluation of response to Intracavitary Radiotherapy

\begin{tabular}{lcccccc}
\hline & CIS & Ta & T1 & T2 & T3 & Total \\
\hline CR & 7 & 4 & 1 & 1 & 1 & 14 \\
NC & 5 & 2 & 2 & 0 & 5 & 14 \\
\hline CR rate & $7 / 12$ & $4 / 6$ & $1 / 3$ & $1 / 1$ & $1 / 6$ & $14 / 28$ \\
\hline
\end{tabular}


Fig. 5 Local control rate after Intracavitary Radiotherapy.

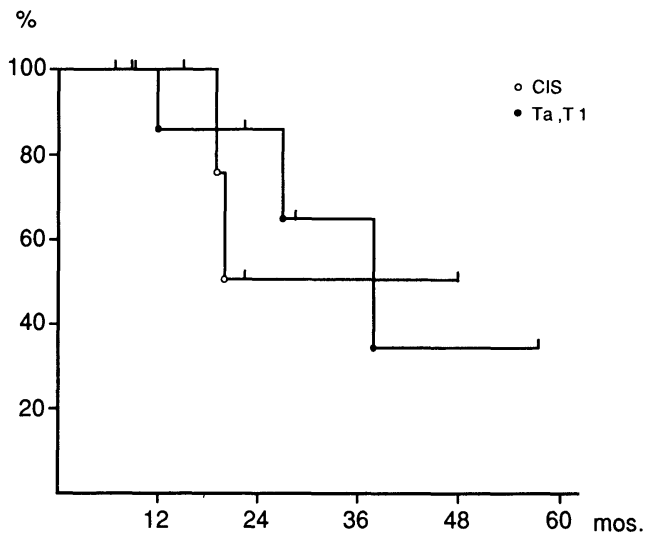

Fig. 6 Survival rate after Intracavitary Radiotherapy.

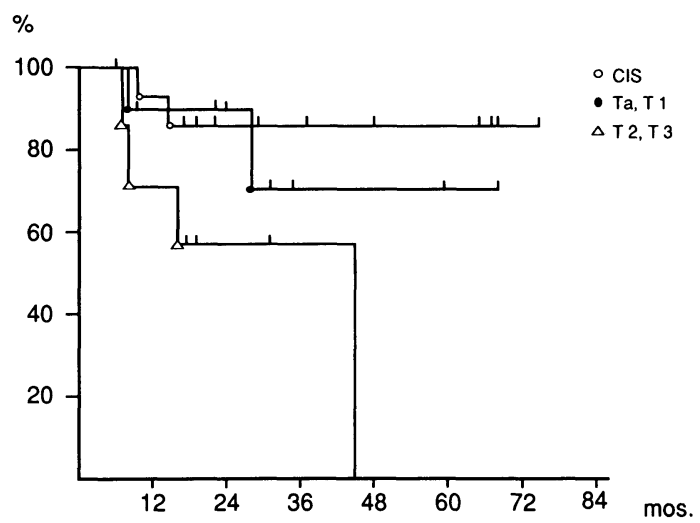

をFig. 5 に示した。

1) CIS: CR の 5 例中 3 例で再発がみられず，その 期間は15〜48力, 平均28.3力月であった。 2 例で再 発がみられ, 再発までの期間は平均19.5力月であった。 効果判定上 NC の 2 例は経過観察中であるが, 平均 18 カ月後において明らかな腫瘍の進行はみられていな い.

2) $\mathrm{Ta}, \mathrm{T} 1: \mathrm{CR}$ の 5 例中 4 例で再発がみられず, そ の期間は $8 \sim 58$ 月, 平均 25.8 月であった. 1 例で 38 力後再発がみられ, 膀胼全摘術を施行, Dysplasia を有した 1 例は, 27 月後再発をみた. NCのうち 3 例 で残存腫瘍に対し TUR (TUEC) を行い, 2 例が 6 力 月, 22 力月再発がみられず, 1 例は 12 力月後再発, 経 過観察した 1 例は19カ月後より腫瘍の増大をみた。
Table 8 Side effect of Intracavitary Radiotherapy

\begin{tabular}{lc}
\hline & Patients No. \\
\hline Mild & 14 \\
Moderate & 9 \\
Severe & 1 \\
No adverse effect & 5 \\
\hline
\end{tabular}

Fig. 7 Rectal dose. Rectal dose was less than 30Gy in all measured cases.

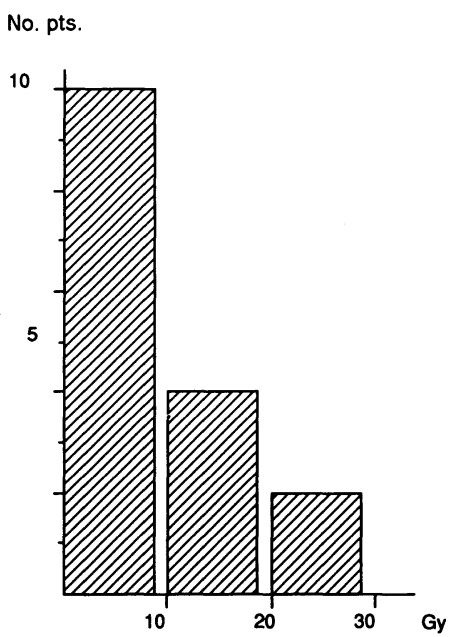

3） $\mathrm{T} 2, \mathrm{~T} 3: \mathrm{CR}$ の 2 例が平均 23.5 力再発がみら れなかった。

全例の生存率（Fg. 6) は, CIS および表在性腫瘍で は, 遠隔転移は認められず, 癌死もなかったが, 浸潤 性腫瘍では 4 例が平均19カ月で癌死した。

副反応は，尿道痛，排尿痛，頻尿等が主であり，29 例中24例 (82.8\%) にみられたが症状の強いものは 1 例のみであった（Table 8). 症状は特に照射直後に強 く，照射用カテーテル挿入による機械的刺激による影 響も強いと考えられた。多くは治療終了とともに徐々 に軽快し，いずれも保存的に治療可能であった。また， 16例において直腸線量が測定されたが10Gy 未満 10 例, 10 20Gy 未満 4 例, 20〜30末満 2 例と 30Gy を越 える症例はなく，放射線による直腸障害はみられな かった (Fig. 7).

膀脱癌に対する放射線療法は，単独または併用療法 の一つとして，外照射を中心に一部で組織内照射5)6), 術中照射 ${ }^{7)}$, 腔内照射8)等の方法が行われている. 外照 射は全膀脱壁から周囲リンパ節等を含めた広範囲への 
Table 9 Comparison of Radiotherapeutic Approach

\begin{tabular}{lcccc}
\hline & Technique & $\begin{array}{c}\text { Tumor } \\
\text { Dose }\end{array}$ & $\begin{array}{c}\text { Irradiated } \\
\text { Portion of } \\
\text { Bladder }\end{array}$ & $\begin{array}{c}\text { Normal } \\
\text { Tissue } \\
\text { Reaction }\end{array}$ \\
\hline $\begin{array}{l}\text { External } \\
\text { Radiation }\end{array}$ & Simple & Moderate & Whole & Frequent \\
$\begin{array}{l}\text { Implant } \\
\begin{array}{l}\text { Intra-operative } \\
\text { Radiotherapy }\end{array}\end{array}$ & Complicated & very High & Partial & Rare \\
$\begin{array}{l}\text { Intracavitary } \\
\text { Radiotherapy }\end{array}$ & Simple & High & Whole & Rare \\
\hline
\end{tabular}

Table 10 Reports of Intracavitary Radiotherapy for Bladder

\begin{tabular}{lcccl}
\hline & Total Dose (Gy) & Stage & \multicolumn{2}{l}{ Relapse Free Rate (Duration) } \\
\hline $\begin{array}{l}\text { Friedmann \& } \\
\text { Lewis }\end{array}$ & $55 \sim 110$ & A $~$ & $56 \%(19 / 34)$ & (5 years) \\
Hewitt & $30 \sim 70$ & CIS & $67 \%(8 / 12)$ & (33 months : mean) \\
& & A & $40 \%(14 / 35)$ & (40 months : mean) \\
Russell * & $20 \sim 32$ & T1 , T2 & $73 \%(11 / 15)$ & (48 months : mean) \\
\hline \multicolumn{4}{c}{ * : Combined with external radiation } \\
Low dose rate was adopted in all reports
\end{tabular}

照射が可能であるが，周囲臓器への照射障害，腫瘍が 残存した場合の炎症性癒着による salvage operation への影響等の問題がある。組織内照射や術中照射は, 腫瘍に対し高線量を投与でき, 周团臓器への障害も少 ないが，手技的にやや難であり，また，照射範囲が膀 胱の一部に限られるため, 膀胱癌の多中心性発生とい う性質には不利である，腔内照射法は，膀脱壁全体に 高線量の投与が可能とされ，かつ，その線量分布より 周囲組織への障害が少ないため, 合併症が軽減でき, また照射後 salvage operationが必要になってもそれ を妨げない，などの利点をもつと考壳られている (Table 9).これらの理由により, 我々は膀胱癌に対す る放射線療法として, 腔内照射法を選択し，1984年よ りその臨床研究に入った。

1949年，1958年に Friedman，Lewis ら ${ }^{91} は$ ，膀胱癌 に対する腔内照射法が非常に良好な治療法であること を最初に報告した，以後，同様にその有効性を示す報 告が散見される810) (Table 10)。しかしながらこれま での方法では, 用いる線源の強度が小さく, 低線量率 であるために，照射に長時間を要すること，その間の 患者の管理, 特に尿貯留により膀胱が抎張するため線 源と膀胼壁との距離が延長し，計画線量を照射しえな いこと, また線源挿入時の医療従事者の被爆などの理
由により，実際には姫とんど行われていないのが現状 である。しかし我々は，子宮頸癌に対し用いられてい る High dose rate remote afterloading system 用することにより，これらの問題点を活涪解決するこ とができた。をず，高線量率線源を用いるため，一回 照射時間は約 5 分前後と短時間であり，その間の尿貯 留による膀胱変形等の問題は汪とんどなく，また，医 療従事者は別室にて操作を行うため被爆は皆無であっ た (Table 11).

治療効果では, Hewitt らの報告と同じょうに, CIS

Table 11 Comparison between Low Dose Rate and High Dose Rate Intracavitary Radiotherapy

\begin{tabular}{lccc}
\hline & Apprication & Urine & Personnel \\
& Time & Drainage & Exposure \\
\hline Low Dose Rate & few days & Necessary & Inevitable \\
High Dose Rate & $\mathbf{5 \sim 1 0 ~ m i n .}$ & Unnecessary & Unlikely \\
\hline
\end{tabular}

Fig. 8 Histological change after Intracavitary Radiotherapy in CIS case. before (A), after (B). Tumor cells were ablated and pyknotic.
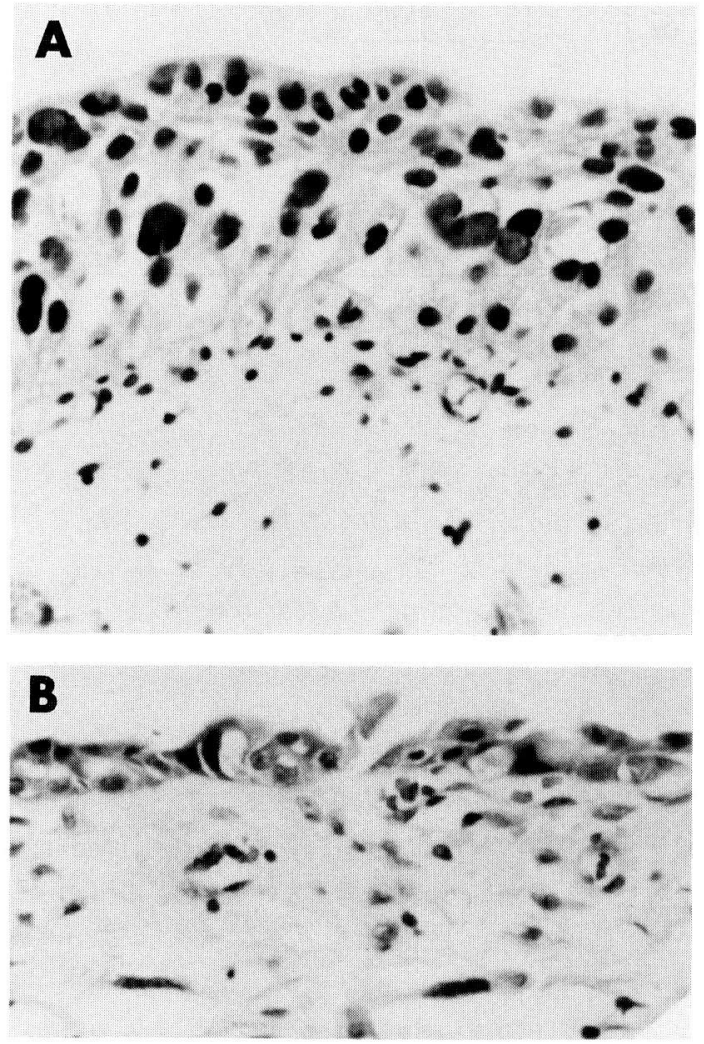
を含む表在性腫瘍に良好な結果がえられた。本療法が CIS や表在性腫瘍に有効であることを示唆する成績と して，その組織学的変化があげられる。たとえば，自 験例での全摘標本に扔いて照射前の CIS (Fig. 8A) が，20Gy 照射後には著明な核の濃縮を標本全般にわ たって認めた (Fig. 8B). 腔内照射後の腫瘍の組織学 的変化は, 広範囲にわたる粘膜上皮の剥離, 脱落傾向 が強いことである. 現在, CIS や再発を繰り返す表在性 腫瘍に対しては抗癌剂や BCG の膀胱内注入療法が有 効とされている. ADM およびその誘導体である Tetrahydropyranyl-adriamycin (THP)の表在性腫瘍 (Ta，T1）に対する有効率（CR+PR）は，それぞれ $27 \sim 66 \%^{11112)}, 56 \sim 63 \%^{12113)}$ ，BCG に打いては表在性 腫瘍 ( Ta，T1) に対する CR 率は $36 \sim 66 \%{ }^{14) \sim 17)}$, CIS に対しては59 94\% ${ }^{14) ~ 19)}$ と報告されている. 自験例で は，CIS および表在性腫瘍（Ta，T1）に対する CR 率 は，それぞれ $58.3 \% ， 55.6 \%$ と，現時点では膀脱内注 入療法に比べより有効な治療法とは言えないが，いま だ種々の問題点を含むこの分野での治療法の一つとし て今後も検討に值するものであると考兄られる。

一方，T2，T3に対する CR 率は $2 / 7(28.6 \%)$ ，特に T3のみでは $1 / 6(16.7 \%)$ と低く，浸潤性腫瘍に対する 本療法の現状での有効性はないと考兄られた。

照射線量に関しては, 線量を増やせば局所制御の可 能性は高くなると考兄られるが，自験例では総線量と 治療成績の間に有意な相関はみられなかった。

副反応に関しては，現在の標準投与線量 40 50Gy では重篤な障害はみられていない，実際，16例におい て直腸線量が測定されたが，30Gyをこ光る症例はな く, 直腸障害はみられなかった。 また, 術前照射とし て本法が行われた 6 例と 38 力後再発した 1 例で膀胱 全摘術が行われたが，手術を困難にするような周囲組 織への癒着等の变化はみられなかった。

本照射法はその線量分布より，膀胱深部筋層，周囲 組織への障害が少なく，合併症を軽減できるといら利 点をもつが，反対に膀胼壁深部や周囲リンパ節等への 効果は期待しがたい。

よって, 本療法は, CIS を含む表在性腫瘍に適応され るものと考兄られるが，治療効果をより高めていくた めには, 放射線の増感剂併用等の工夫を今後は考慮す ることも必要と思われる。

\section{結 語}

29例の膀胼癌患者に対し, High dose rate remote afterloading systemを用いた腔内照射法を施行し次
の結果を得た。

1. CIS, 表在性腫瘍（Ta， T1）, 浸潤性腫瘍（T2,

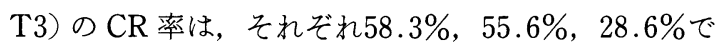
あった。

2. 総線量が $40 \sim 60 \mathrm{~Gy}$ まででは，重篤な副反応はみ られなかった。

3. 本療法は, CIS や再発を繰り返す表在性腫瘍に対 し有効な治療法と考兄られた。

稿を終えるにあたり，本研究を直接御指導いただきまし た関西労災病院放射線科西山䔆司先生に深く感謝の意を表 します。また，御協力いただきました，松下全巳先生(現柏 原病院), 田中宏和先生 (現神戸大学) に深謝申しあげます。

\section{文献}

1) Grossman, H.B.: Current therapy of bladder carcinoma. J. Urol., 121, 1-7, 1979.

2) Whitmore, W.F. Jr. and Marshall, V.F.: Radical total cystectomy for cancer of the bladder : 230 consecutive cases five years later. J. Urol., 87, 853-868, 1962.

3）久保 隆，大日向充：膀胼腫瘍に対する放射線の 現況. 臨泌，43，461-470, 1989.

4）大星章一, 下里幸雄, 板倉克明, 梅垣一郎：放射線 療法の病理 (1) 癌組織の治瘾過程の組織学的追跡 (その 1). 医学のあゆみ，1，618一625，1967.

5) Van der Werf-Messing, B. and Hop, W.C.J. : Carcinoma of the urinary bladder (category $\mathrm{T} 1 \mathrm{NxMo}$ ) treated either by radium implant or by transurethral resection only. Int. J. Radiat. Oncol. Biol. Phys., 7, 299-303, 1981.

6) Van der Werf-Messing, B., Menon, R.S. and Hop, W.C.J.: Cancer of the urinary bladder category T2, T3, (NxMo) treated by interstitial radium implant: Second report. Int. J. Radiat. Oncol. Biol. Phys., 9, 481-485, 1983.

7) Matumoto, K., Kakizoe, T., Mikuriya, S., Tanaka, T., Kondo, I. and Umegaki, Y.: Clinical evaluation of intraoperative radiotherapy for carcinoma of the urinary bladder. Cancer, 47 , 509-513, 1981.

8) Hewitt, C.B., Babiszewski, J.F. and Antunez, A. R.: Update on intracavitary radiation in the treatment of bladder tumors. J. Urol., 126, 323-325, 1981.

9) Friedman, M. and Lewis, L.G.: Irradiation of carcinoma of the bladder by a central intracavitary radium or cobalt 60 source (the Walter Reed technique). Amer. J. Roentgen., 79, 6-31, 1958.

10) Russell, K.J., Koh, W.J., Russell, A.H., Griffin, B.R., Markette, K.L., Tong, D.Y. and Griffin, T. 
W.: Combined intracavitary and external beam irradiation for superficial transitional cell carcinoma of the bladder: An alternative to cystectomy for patients with recurrence after intravesical chemotherapy. J. Urol., 141, 30-32, 1989.

11）松村陽右：Adriamycinによる治療注入の成績, 表在性膀胱腫瘍に対する注入療法, p. 35-39, 蟹 書房, 東京, 1985.

12）川村寿一，栃木宏水，小幡浩司，上田公介，太田黒 和生, 栗山 学, 篠田正幸, 成瀬克邦, 村瀬達良, 長谷川泰洋: 表在性膀胱腫瘍に対する Pirarubicin (THP) の膀胱内注入療法. 泌氺紀要, 38, 379-385, 1992.

13）新島端夫：共同研究による $(2 " \mathrm{R})-4^{\prime}$ - O tetrahydropyranyl-adriamycin (THP) phase II study. 癌と化学療法, 13, 224-231，1986.

14) Morales, A.: Long-term results and complications of intracavitary Bacillus Calmette-Guerin therapy for bladder carcinoma. J. Urol., 132, 457-459, 1984.

15) Brossman, S.A.: BCG in the management of superficial bladder cancer. Urology, Suppl., 23, 82-87, 1984.

16) deKernion, J.B., Huang, M.Y., Linder, A., Smith, R.B. and Kaufman, J.J.: The management of superficial bladder tumors and carcinoma in situ with intravesical Bacillus Calmette-Guerin. J. Urol., 133，598-601， 1985.

17）赤座英之, 亀山周二, 垣添忠夫, 小島弘敬, 小磯謙 吉, 阿曾佳郎, 新島端夫：表在性膀胱癌打上び膀胱 上皮内癌に対する $\mathrm{BCG}$ 東京 172 株の膀脱内注入療 法の抗腫瑒効果と再発予防効果の検討. 日泌尿会 誌, 83，183-189, 1992.

18) Brossman, S.A.: The use of Bacillus Calmette-Guerin in the therapy of bladder carcinoma in situ. J. Urol., 134, 36-39, 1985.

19) Herr, H.W., Pinsky, C.M., Whitmore, W.F. Jr., Sogani, P.C., Oettgen, H.F. and Melamed, M.R. : Long-term effect of intravesical Bacillus Calmette-Guerin on flat carcinoma in situ of the bladder. J. Urol., 135, 265-267, 1986. （1993年 2 月 9 日受付，12月 3 日受理，特別掲載） 